\title{
DESAIN ENERGI HIBRIDA SOLAR PANEL DAN LISTRIK UNTUK PENERANGAN AREA PARKIR
}

\author{
Sarono Widodo ${ }^{1}$, Agus Rochadi ${ }^{2}$, Muhammad Anif ${ }^{3}$ \\ ${ }^{1,2,3}$ Politeknik Negeri Semarang \\ Email: ${ }^{1}$ sarono.widodo@polines.ac.id, ${ }^{2}$ agus.rochadi@polines.ac.id, ${ }^{3}$ muhammad.anif@ polines.ac.id
}

\begin{abstract}
Abstrak
Abstrak--Desain energi hibrida dengan memanfaatan energi matahari dan energi listrik (PLN) merupakan penelitian lanjutan sebagai sumber energi penerangan model sel pada area parkir. Energi yang dihasilkan dari matahari melalui panel surya yang tersimpan pada baterai digunakan sebagai sumber utama melalui sistem hibrida. Sistem ini dirancang menggunakan dua buah solar panel (110 Wp), Mesonic MF 1500 dan baterai Deep cycle 12V/100Ah untuk mensuplai lampu penerangan area parkir $100-250$ watt selama tiga sampai empat jam. Dengan menggunakan solar panel pada sistem hibrida ini maka energi listrik yang dihasilkan mampu untuk mensuplai lampu penerangan area parkir.
\end{abstract}

Kata Kunci: hibrida, solar panel,penerangan

\begin{abstract}
Abstract The design of hybrid energy by utilizing solar power and electrical energy (PLN) is further research as a source of energy for cell model lighting in the parking area. The electricity generated from the sun through solar panels stored on the battery as the primary source through a hybrid system. The system is designed using two solar panels (110 Wp), Mesonic MF 1500 and Deep cycle 12V/ 100Ah batteries to supply 100 - 250-watt parking lot lighting for three to four hours. By using solar panels in this hybrid system, the electricity produced can provide light in the parking area.
\end{abstract}

Keywords: hybrid, solar panels, lighting

\section{PENDAhULUAN}

Kebutuhan energi listrik dalam negeri terus mengalami peningkatan setiap tahunnya seiring dengan peningkatan pertumbuhan ekonomi nasional. Rata-rata kebutuhan listrik secara nasional mengalami pertumbuhan sebesar $6,5 \%$ per tahun selama kurun waktu 17 tahun (2003-2020) pada 22 wilayah pemasaran listrik PLN. Total kebutuhan listrik nasional sebesar 91,72 TWh di tahun 2003 menjadi 272,34 TWh pada tahun 2020. Sektor komersial mengalami pertumbuhan paling tinggi yaitu sebesar $7,3 \%$ per tahun selanjutnya disusul pertumbuhan kebutuhan listrik untuk rumah tangga sebesar 6,9\%. Pertumbuhan kebutuhan listrik ini sangat beralasan mengingat untuk meningkatkan perekonomian di Indonesia, pemerintah meningkatkan sektor pariwisata yang akan berpengaruh terhadap pertumbuhan sektor komersial (Moch.Muchlis,2003).
Pemerintah selain menyediakan kebutuhan energi listrik untuk jangka panjang juga telah melakukan upaya-upaya termasuk pengaturan penggunaan listrik khususnya di pemerintahan melalui pengematan penggunaan listrik di berbagai bidang. Melalui Peraturan Menteri Energi dan Sumber Daya Mineral Republik Indonesia Nomor 13 tahun 2012 tentang Penghematan Pemakaian Tenaga Listrik. Penghematan pemakaian tenaga listrik dilakukan dengan target akhir sebesar $20 \%$. Pelaksanaan penghematan pada penggunaan sistem tata udara, tata cahaya dan peralatan pendukung. Penghematan tenaga listrik untuk sistem tata cahaya dilakukan dengan penggunaan lampu hemat energi sesuai peruntukannya, mengatur daya listrik maksimum untuk pencahayaan seperti untuk tempat parkir 4 watt $/ \mathrm{m}^{2}$ dengan tingkat pencahayaan paling rendah 100 lux, mengatur saklar berdasarkan kelompok area sesuai 
kebutuhan (Peraturan Menteri ESDM No.13, 2012).

Dalam upaya mendukung pemerintah tersebut, telah dilakukan penelitian penghematan pemakaian tenaga listrik untuk penerangan area parkir menggunakan metode sel penerangan. Penerangan pada area parkir di atur berdasarkan sel (penerangan sel 1, sel 2 dan sel 3) kebutuhan (Sarono Widodo,2017). Hasil penelitian menunjukkan bahwa penggunaan lampu LED berdaya 7 Watt memiliki intensitas cahaya sebesar 50 lux pada ketinggian 2,5 m dan LED 10,5 Watt pada ketinggian yang sama memiliki tingkat intensitas cahaya sebesar 100 lux. Walaupun sudah dilakukan penelitian dengan mengupayakan penghematan tenaga listrik dengan metode sel penerangan dan penggunaan lampu LED berdaya rendah namun semua energi yang digunakan masih menggunakan tenaga listrik. Seperti dalam rancangan penelitian lanjutan, maka akan dibangun sumber energi hibrida yang bersumber dari energi matahari dengan memanfaatkan panel surya (solar sel) dan dipadukan dengan energi listrik. Sumber energi listrik yang dihasilkan oleh energi matahari digunakan sebagai sumber energi atau tenaga listrik utama untuk memenuhi kebutuhan energi pada lampu penerangan area parkir. Dengan menggunakan sumber energi hibrida ini maka pemakaian tenaga listrik dari PLN akan lebih banyak dihemat.

\section{METODE}

Metode dalam penelitian ini adalah tahapan perancangan untuk menghasilkan tenaga listrik dari solar sel yang dipadukan dengan tenaga listrik PLN menggunakan metode hibrida untuk kebutuhan energi pada penerangan area parkir. Tahapan perancangan adalah sebagai berikut:

1. Merancang sistem energi hibrida untuk kebutuhan penerangan area parkir.

Sistem hibrida merupakan perpaduan dua sumber energi (pembangkit) seperti solar sel (energi matahari) dengan diesel atau solar sel dengan listrik dari PLN dengan menggunakan teknik satu arah sumber (pembangkit) yang akan mensuplai beban. Pada rancangan sistem hibrida ini digunakan dua pembangkit yaitu solar sel dan listrik. Sistem hibrida yang dirancang untuk beban berupa penerangan area parkir. Ketika suplai ke beban diberikan oleh solar sel maka secara otomatis suplai dari listrik PLN akan diputus. Sebaliknya ketika suplai dari listrik digunakan karena baterai tidak mampu mensuplai maka otomatis hubungan dari solar sel akan diputus
(Hasyim,2012). Prinsip dari rancangan ini adalah memanfaatkan sumber energi solar sel menjadi suplai utama dan sumber listriknya sebagai cadangan ketika baterai sudah tidak mampu lagi mensuplai beban. Perancangan kebutuhan energi dengan memadukan antara sumber energi matahari (solar sel) dengan energi listrik PLN dengan sistem hibrida untuk penerangan area parkir dengan metode sel ditunjukkan seperti pada Gambar 1 (Sarono Widodo,2017). Pada Gambar 1 terdapat dua buah blok, yaitu blok bawah merupakan hasil penelitian sebelumnya dimana untuk memenuhi kebutuhan penerangan parkir sepenuhnya menggunakan tenaga listrik dari PLN. Sedangkan pada blok bagian atas adalah sumber energi yang dihasilkan dari solar sel yang dirancang untuk menghasilkan sistem hibrida dengan energi listrik.

2. Menghitung kebutuhan solar panel dan baterai untuk memenuhi penerangan area parkir berdaya 100 sampai dengan 250 watt.

Untuk memenuhi kebutuhan suplai beban (lampu penerangan untuk area parkir) dilakukan perhitungan untuk menentukan kebutuhan kapasitas solar sel dan kapasitas baterai sehingga memenuhi kebutuhan penerangan selama tiga sampai empat jam.

3. Menyediakan perangkat sistem hibrida.

Perangkat yang harus disediakan seperti solar sel, baterai, perangkat hibrida yang didalamnya sudah terdapat Battery Charger Regulator (BCR), inverter dan switching controller.

4. Pembuatan sistem hibrida.

Tahapan ini adalah membuat tiang dan braket untuk solar sel serta instalasi sistem hibrida guna dilanjutkan pada kegiatan pengujian solar sel dan sistem hibrida keseluruhan.

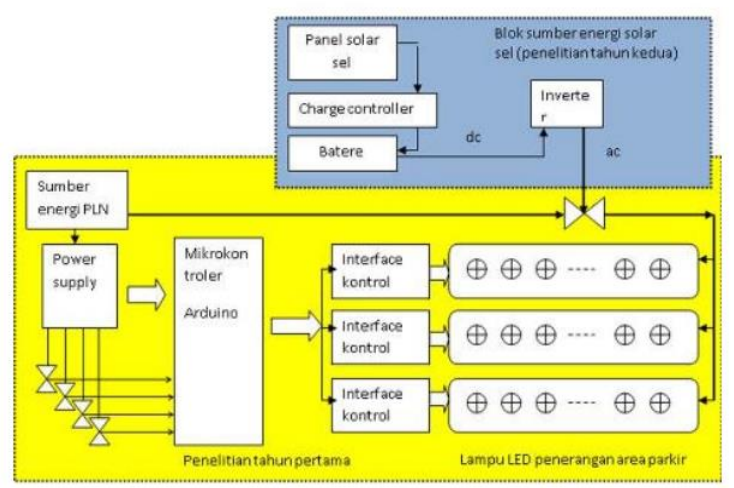

Gambar. 1 Desain sumber energi hibrida pada penerangan area parkir

Sumber : Data primer penelitian tahun pertama, 2017. 


\section{HASIL DAN PEMBAHASAN}

\section{Perancangan Sistem Hibrida}

Perancangan sistem hibrida seperti ditunjukkan pada Gambar 2. Terdapat lima blok yaitu solar sel (solar panel), perangkat sistem hibrida, baterai penyimpanan, pembangkit (listrik) dan beban. Blok perangkat sistem hibrida di dalamnya terdapat battery charger regulator yang berfungsi untuk mengatur pengisian baterai, inverter yang akan mengubah arus dan tegangan DC yang bersumber dari baterai menjadi tegangan 220 volt dan swiching controller yang akan mengatur suplai dari kedua pembangkit. Dibutuhkan sistem pengkabelan baik pengkabelan dari solar sel ke sistem hibrida, pengkabelan baterai ke sistem hibrida, pengkabelan listrik dan beban ke sistem hibrida.

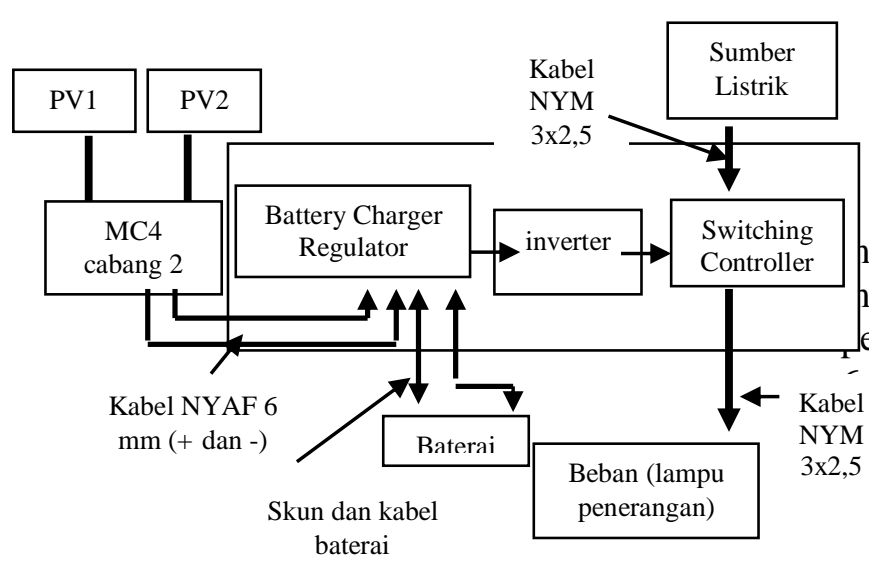

Gambar.2 Rancangan sistem hibrida

\section{Menghitung Kebutuhan Panel Solar Sel dan} Baterai

berisi Kebutuhan solar sel (panel surya) untuk membangun pembangkit listrik tenaga surya (PLTS) sistem hibrida guna memenuhi kebutuhan beban yang berkisar antara 100 sampai 250 watt dilakukan perhitungan :

\section{a. Perhitungan Kapasitas Panel solar sel}

Penggunaan energi yang bersumber dari matahari dengan menggunakan modul solar sel untuk penerangan area parkir. Modul solar sel yang digunakan adalah modul photovoltaics yang dapat menghasilkan listrik searah (DC) (Junial, 2012). Besarnya beban total dihitung berdasarkan total daya reaktif dikalikan lama penggunaan (Abdul Hafid,2017).

$\mathrm{E}_{\mathrm{B}}=\mathrm{W}_{\text {tot }} \mathrm{x}$ Lama penggunaan PLTS (1)

$\mathrm{E}_{\mathrm{B}}=$ beban total $(\mathrm{Wh})$

$\mathrm{W}_{\text {tot }}=$ daya reaktif $(\mathrm{W})$

Kebutuhan sistem hibrida dengan beban tertinggi adalah 250 Watt dengan lama penggunaan 4 jam/hari, maka beban totalnya adalah:
$\mathrm{E}_{\mathrm{B}}=$ beban tertinggi $\mathrm{x}$ lama penggunaan PLTS/hari

$$
\begin{aligned}
& =250 \mathrm{~W} \mathrm{x} 4 \\
& =1000 \mathrm{Wh} .
\end{aligned}
$$

Pada rancangan sistem hibrida mensuplai kebutuhan beban sistem hanya pada malam hari selama 4 jam, maka besarnya energi beban yang harus disuplai sebesar ;

$$
\begin{aligned}
\mathrm{E}_{\mathrm{A}} & =100 \% \\
& \ldots \ldots \ldots \ldots \ldots \ldots \ldots \ldots \ldots \ldots \ldots \ldots \ldots \ldots \ldots \ldots \ldots \ldots \ldots \ldots \ldots \\
= & 100 \% \mathrm{x} 1000 \mathrm{Wh} \\
= & 1000 \mathrm{Wh} .
\end{aligned}
$$

Jika diasumsikan bahwa rugi-rugi pada sistem sebesar 15\%, maka besarnya energi sistem adalah:

$\mathrm{E}_{\mathrm{T}}=\mathrm{E}_{\mathrm{A}}+$ rugi-rugi sistem

$\mathrm{E}_{\mathrm{T}}=\mathrm{E}_{\mathrm{A}}+\left(15 \% \quad \mathrm{x} \quad \mathrm{E}_{\mathrm{A}}\right)$

$\mathrm{E}_{\mathrm{T}}=$ energi sistem

Jadi keseluruhan energi adalah:

$\mathrm{E}_{\mathrm{T}}=1000 \mathrm{Wh}+(15 \% \times 1000 \mathrm{Wh})$

$$
=1150 \mathrm{Wh}
$$

Bila nilai radiasi matahari terendah adalah 52 , aaka besarnya nilai insolasi matahari adalah embagi nilai radiasi matahari dengan lama enyinaran dengan asumsi selama 8 jam/hari, yaitu

$\mathrm{W} / \mathrm{m}^{2} /$ hari. Jika faktor penyesuaian pada anyakan instalasi PLTS adalah sebesar 1,1; za kapasitas daya solar sel adalah:

Kapasitas Daya Modul surya

$=\left[\left(\mathrm{E}_{\mathrm{T}} /\right.\right.$ insolasi matahari $) \mathrm{x}$ faktor penyesuaian]....(4)

$$
\begin{aligned}
& =(1150 \mathrm{Wh} / 6,5) \times 1,1 \\
& =194,61 \mathrm{Watt}
\end{aligned}
$$

Pada Jadi besarnya kapasitas daya modul solar sel adalah 194,61 Watt Peak. Dari hasil perhitungan ini maka dibutuhkan dua buah panel solar sel yang masing-masing berkapasitas 110 WP. Efisiensi modul solar sel Photovoltaic (PV) untuk kebutuhan pembangkit hibrida adalah (S.Kurniati,2013):
$\eta=\left[\left(\mathrm{P}_{\max } / \mathrm{P}_{\min }\right)\right.$
$\mathrm{P}_{\max }=$ daya keluaran maksimum solar sel
$\mathrm{P}_{\min }=$ daya masukan yang tertera pada panel solar sel
$100 \%]$

Modul solar sel $110 \mathrm{Wp}$ module type: SZYLMono-18 dengan spesifikasi sebagai berikut:
Peak Power

Open Circuit Voltage

Short Circuit Current

Peak Voltage

Peak Current

Test Condition: intensitas matahari : $1000 \mathrm{~W} / \mathrm{m}^{2}$ Suhu : $25^{\circ} \mathrm{C}$

$$
\text { : } 110 \text { Watt }
$$

\section{: 6,40 Ampere} : 18,5 Volt : 5,95 Ampere 
Fill Factor

$(F F)=\left[\begin{array}{lll}\mathrm{v}_{\mathrm{mp}} & \mathrm{x} & \mathrm{i}_{\mathrm{mp}}\end{array}\right] /\left[\begin{array}{lll}\mathrm{v}_{\mathrm{oc}} & \mathrm{x} & \mathrm{i}_{\mathrm{oc}}\end{array}\right]$ (6)

Kisaran nilai fill factor antara 0,7 sampai dengan 0,85 . Semakin besar nilai fill factor maka kerja panel solar sel akan semakin baik karena nilai efisiensinya akan semakin tinggi (Zian.I,2018).

Daya maksimum $\left(\mathrm{P}_{\max }\right)=\mathrm{V}_{\mathrm{OC}} \times \mathrm{I}_{\mathrm{SC}} \mathrm{x} \quad \mathrm{FF}$ (7)

Dengan menggunakan persamaan (5),(6) dan (7) maka dapat dihitung efisiensi modul solar sel sebagai berikut:

$$
\begin{aligned}
& \text { Fill Faktor }(\mathrm{FF})=\left[\mathrm{v}_{\mathrm{mp}} \times \mathrm{i}_{\mathrm{mp}}\right] /\left[\mathrm{v}_{\mathrm{oc}} \times \mathrm{i}_{\mathrm{oc}}\right] \\
& =(18,5 \times 5,95) /(21,9 \times 6,4) \\
& =0,783
\end{aligned}
$$

Kurva karakteristik V-I panel solar sel seperti ditunjukkan pada Gambar 3. Karakteristik berdasarkan spesifikasi modul yang menunjukkan hubungan antara arus dan tegangan. Kurva karakteristik V-I pada saat suhu yang menyinari panel adalah $25^{\circ} \mathrm{C}$.

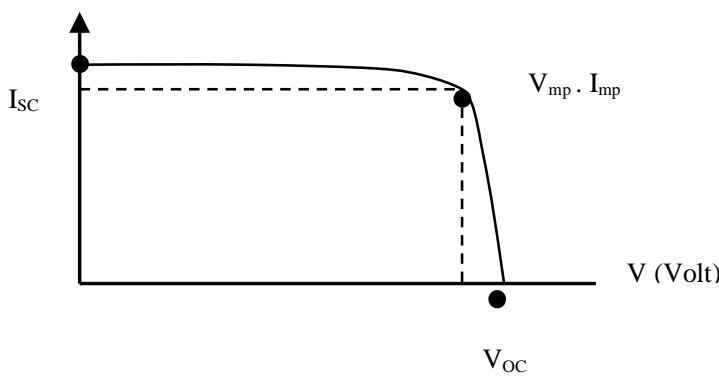

Gambar.3 Karakteristik V-I panel solar sel

\section{b. Perhitungan Kapasitas Panel solar sel}

Baterai untuk membangun sistem hibrida pada tenaga listrik surya adalah jenis deep cycle, dimana kapasitas baterai dihitung berdasarkan rumus berikut (Andi,2017):

Kapasitas baterai $=A h=\left[\left(\begin{array}{ll}n & x\end{array}\right.\right.$

$\left.\left.\mathrm{E}_{\mathrm{T}}\right) /\left(\mathrm{V}_{\mathrm{S}} \mathrm{xDOD}\right)\right] \ldots(8)$

$\mathrm{Ah}=$ kuat arus/jam $(\mathrm{Ah})$

$\eta=$ efisiensi harian

$\mathrm{E}_{\mathrm{T}}=$ energi sistem $(\mathrm{Wh})$

$\mathrm{Vs}=$ tegangan sistem baterai

DOD $=$ Depth of Discharge $80 \%$

Besarnya kapasitas baterai adalah:

$\mathrm{Ah}=[(0,99 \times 1150) /(12 \times 0,8)]$

$=118,59 \mathrm{Ah}$.

Jika digunakan baterai $100 \mathrm{Ah}$, maka pengisian baterai adalah :

$$
\begin{aligned}
& \mathrm{T}_{1} \quad=(\mathrm{C} / \mathrm{I}) \quad \mathrm{x} \\
& \ldots \ldots \ldots \ldots \ldots \ldots \ldots \ldots \ldots \ldots \ldots \ldots \\
& \mathrm{T}_{1}=\text { waktu pengisian } \\
& \mathrm{C}=\text { kapasitas (Ah) } \\
& \mathrm{I}=\text { Arus pengisian (Ampere) } \\
& 20 \%=\% \text { de-efisiensi }
\end{aligned}
$$

Maka lama pengisian baterai adalah :

$$
\mathrm{T}_{1}=(100 \mathrm{Ah} / 5,95 \mathrm{~A}) \times(1+20 \%)
$$$$
=20,168 \mathrm{jam} \text {. }
$$

Jika digunakan dua panel solar sel berkapasitas $110 \mathrm{Wp}$, maka waktu pengisian baterai berkisar 10,08 jam.

\section{Penyediaan Perangkat Sistem Hibrida}

Hasil perhitungan dan analisa yang telah dilakukan untuk kebutuhan panel solar sel maupun baterai, maka kebutuhan perangkat untuk sistem hibrida dalam penelitian ini adalah:

- Panel Solar sel (Panel Photovoltaics) berkapasitas $110 \mathrm{Wp}$ sebanyak 2 buah

- Baterai Deep cycle 12 V/100 Ah sebanyak 1 buah

- Konektor MC4 Cabang 2 sebanyak 1 pasang

- Konektor MC4 Cabang 1 sebanyak 1 pasang

- Sistem hibrida tipe MF1500 sebanyak 1 buah

- Kabel NYAF 6 mm untuk menghubungkan panel solar sel ke sistem hibrida

- Kabel NYM 3 x 2,5 untuk pengkabelan sumber listrik dan beban

- Skun dan kabel baterai

\section{Pembuatan Sistem Hibrida}

Sistem hibrida yang bersumber dari panel solar sel dan listrik untuk memenuhi kebutuhan penerangan area parkir seperti ditunjukkan pada Gambar 4.

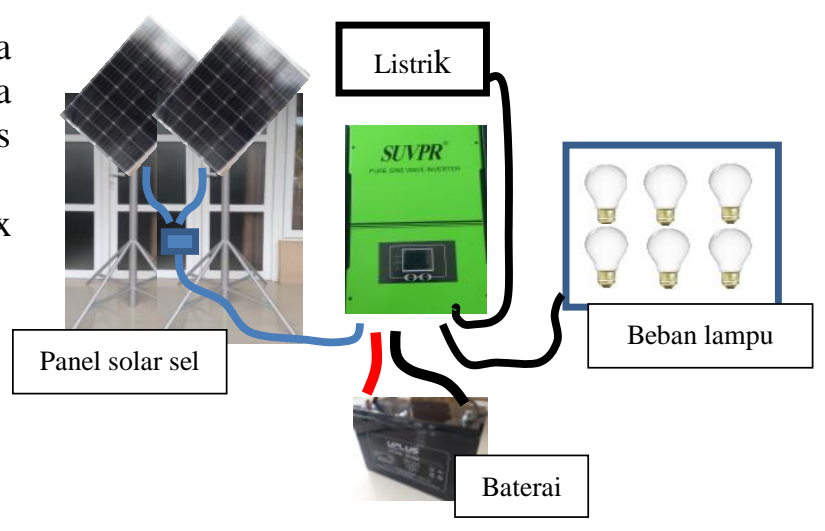

Gambar.4 Instalasi sistem hibrida 


\section{PENUTUP}

\section{Kesimpulan}

Berdasarkan perhitungan pada rancangan sistim hibrida pembangkit energi matahari dengan solar panel dan enegri listrik, maka kebutuhan untuk beban penerangan area parkir dibutuhkan dua buah solar panel (110 Wp), Perangkat Mesonic MF 1500 yang didalamnya terdapat sistem Batery Charger Regulator, Inverter dan Switching Controller; baterai Deep cycle 12V/100Ah untuk mensuplai lampu penerangan area parkir $100-250$ watt selama tiga sampai empat jam. Dengan metode hibrida ini maka penggunaan energi listrik untuk penerangan dapat disuplai sepenuhnya dengan solar panel sehingga penggunaan energi listrik dapat dihemat.

\section{Saran}

Sistem hibrida dengan model pengukuran dan pengontrolan semi-otomatis dapat ditingkatkan sepenuhnya otomatis pada keluaran solar panel dan arus pengisian baterai secara riel-time yang dapat dipantau melalui telepon seluler untuk memberikan informasi keberadaan perangkat sistem hibrida.

\section{Ucapan Terima Kasih}

Penulis mengucapkan terima kasih kepada DRPM Kementerian Riset, Teknologi dan Pendidikan Tinggi yang telah membiayai penelitian PSNI tahun 2018 (tahun ke-2).

\section{DAFTAR PUSTAKA}

Abdul Hafid,Zainal Abidin,Saddam Husain,Rahmat Umar. (2017). Analisa Pembangkit Listrik Tenaga Surya Pulau Balang Lompo. Jurnal Litek:Jurnal Listrik Telekomunikasi Elektronika,Vol.14,No.1 Maret 2017,6-12.

Andi Yulisman,Ira Devi S.,Ramadhan Halid S. (2017). Prototipe Pemanfaatan Panel Surya Sebagai Sumber Energi Pada Sistem Otomasi Atap Stadion Bola. KITEKTRO:Jurnal Online Teknik Elektro,Vol.2,No.1,2017,35-42.

Hasyim A.,Jatmiko,Angga.(2012). Simposium Nasional RAPI XI FT UMS : Intensitas Cahaya Matahari Terhadap Daya Keluaran Panel Sel Surya.

Junial Heri. (2012). Pengujian Sistem Pembangkit Listrik Tenaga Surya Solar Cell Kapasitas 50 WP. Engineering,Vol.4,No.1 2012,47-55.

Moch Muchlis., Adi Darma P. (2003). Proyeksi Kebutuhan Listrik PLN Tahun 2003 S.D 2020. Retrieved from http://www.oocities.org/ markal_bppt/publish/slistrk/slmuch.pdf

Peraturan Menteri Energi dan Sumber Daya Mineral (2012). Nomor 13 Tahun 2012 tentang Penghematan Pemakaian Tenaga Listrik.

Sarono Widodo, Agus Rochadi, Muhammad Anif. (2017). Prosiding $2^{\text {nd }}$ Seminar Nasional IPTEK Terapan (SENIT) Vol 2 (1): Desain Smart City Model Penerangan Area Parkir Menggunakan Metode Sel Lampu LED Hemat Energi Dikontrol Dengan Mikrokontroler.

Sri Kurniati,Sudirman. (2013). Analisis Efisiensi Keluaran Daya Solar Sel Berdasarkan Sudut Kemiringan. Jurnal Media Elektro, Vol.1, No.3,2013,85-88.

Zian Iqtimal,Ira Devi S.,Syahrizal. (2018). Aplikasi Sistem Tenaga Surya Sebagai Sumber Tenaga Listrik Pompa Air. KITEKTRO:Jurnal Online Teknik Elektro, Vol.3,No.1,2018,1-8. 